\title{
Dukungan Suami Terhadap Perilaku WUS (30-50 Tahun) dalam Melakukan Pemeriksaan IVA di Wilayah Kerja Puskesmas Bondongan Tahun 2018
}

\author{
Mei Sondang ${ }^{1}$, Ella Nurlaella Hadi ${ }^{2}$ \\ ${ }^{1}$ Mahasiswi S2 Fakultas Kesehatan Masyarakat, Universitas Indonesia \\ ${ }^{2}$ Dosen Departemen PKIP, Fakultas Kesehatan Masyarakat Universitas Indonesia \\ Email: meisondang05@gmail.com \\ Doi : https://doi.org/10.30787/gaster.v17i2.368 \\ Received: April 2019 | Revised: Mei 2019 | Accepted: Agustus 2019
}

\begin{abstract}
ABSTRAK
Latar Belakang: Kanker serviks adalah tumor ganas primer yang berasal dari sel epitel skuamosa, yang terjadi pada serviks atau leher rahim dan sering disebut sebagai "silent killer". Salah satu upaya untuk mendeteksi kanker serviks adalah dengan melakukan pemeriksaan IVA. Cakupan IVA di Indonesia masih jauh dari yang diharapkan. Tahun 2016, cakupan IVA di Indonesia hanya 5\% dan Jawa Barat sampai tahun 2016 baru 3\%. Sementara itu, cakupan IVA Puskesmas Bondongan tahun 2017 sebanyak 0,8\% dan merupakan cakupan yang terendah diantara 25 Puskesmas yang ada di Kota Bogor. Tujuan: untuk mengetahui hubungan dukungan suami dengan perilaku WUS (30-50 tahun) dalam melakukan pemeriksaan IVA di wilayah kerja Puskesmas Bondongan, Kota Bogor Tahun 2018. Metode: penelitian ini merupakan penelitian kuantitatif dengan rancangan cross sectional, dengan responden WUS (30-50 tahun) sebanyak 59 orang. Hasil: WUS yang melakukan pemeriksaan IVA sebanyak 27,1\% dan WUS yang mendapat dukungan suami sebanyak 50\% yang melakukan pemeriksaan IVA. Berdasarkan hasil uji chi-squarediperoleh tidak ada hubungan karakteristik (usia, nilai p=0,791, pendidikan, nilai $p=0,956$, pekerjaan, nilai $p=0,116)$ dengan perilaku WUS (30-50 tahun) dalam melakukan pemeriksaan IVA. Ada hubungan antara dukungan suami $(p=0,001)$ dengan perilaku WUS (30-50 tahun) dalam melakukan pemeriksaan IVA. Diharapkan kepada petugas kesehatan Puskesmas Bondongan untuk terus mensosialisasikan tentang pemeriksaan IVA kepada WUS (30-50 tahun) dan juga kepada suami.
\end{abstract}

Kata Kunci: Kanker serviks; pemeriksaan IVA; Dukungan suami

\section{ABSTRACT}

Cervical cancer is a primary malignant tumor originating from squamous epithelial cells, which occurs in the cervix or cervix and is often referred to as the "silent killer". One effort to detect cervical cancer is by carrying out IVA examination. The coverage of IVA in Indonesia is still far from expected. In 2016, coverage of IVA in Indonesia was only 5\% and West Java until 2016 was only 3\%. Meanwhile, the coverage of IVA in Bondongan Health Center in 2017 is $0.8 \%$ 
and is the lowest coverage among the 25 Puskesmas in Bogor City. Objective: to find out the relationship between husband's support and WUS (30-50 years) behavior in conducting IVA examinations in the work area of Bondongan Health Center, Bogor City in 2018. Method: This study was a quantitative study with cross sectional design, with respondents WUS (30-50 year) as many as 59 people. Results: WUS who conducted IVA examinations were $27.1 \%$ and WUS who received husband support were $50 \%$ who conducted IVA examinations. Based on the results of the chi-square test, there was no relationship between characteristics (age, $p$ value $=0.791$, education, $p$ value $=0.956$, occupation, $p$ value $=0.116)$ with WUS (30-50 years) behavior in conducting IVA examination. There is a relationship between husband's support $(p=0.001)$ and WUS (30-50 years) behavior in conducting IVA examinations. It is expected that Bondongan Health Center health workers will continue to socialize about IVA examination to WUS (30-50 years) and also to husbands.

Keywords: Cervical cancer; IVA examination; husband's support

\section{PENDAHULUAN}

Indonesia merupakan salah satu negara yang mengalami transisi epidemiologi penyebab kematian. Tahun 1990, penyebab kematian di Indonesia tertinggi disebabkan oleh penyakit menular sebesar $56 \%$ dan tahun 2014 penyebab kematian tertinggi di Indonesia disebabkan oleh Penyakit Tidak Menular (PTM) sebesar 71\% (Kemenkes RI, 2016b). Salah satu PTM yang terjadi pada wanita adalah penyakit kanker serviks.

Kanker serviks adalah tumor ganas primer yang berasal dari sel epitel skuamosa, yang terjadi pada serviks atau leher rahim, suatu daerah pada organ reproduksi wanita yang merupakan pintu masuk kearah rahim, letaknya antara rahim dan liang senggama/ vagina (Notodiharjo, 2002 dalam Riksani, 2016).Kanker serviks sering disebut sebagai “silent killer”, karena tidak memiliki gejala awal yang spesifik, namun ketika penyakit tersebut terdeteksi sudah masuk ke stadium akhir, menyebar ke organ tubuh lainnya, seperti keparu-paru, hati, kandung kemih, vagina, dll (Riksani, 2016)

Penyebab dari kanker serviks adalah Human Papilloma Virus (HPV). Virus ini bersifat eksklusif dan spesifik karena hanya bisa tumbuh dan menyerang sel-sel manusia, terutama pada sel epitel mulut rahim. Sel ini tidak langsung berubah menjadi sel kanker, tetapi berkembang secara bertahap karena pengaruh zat-zat yang bersifat karsinogen (Riksani, 2016). Faktor risiko kanker serviks 
antara lain: 1). Kegiatan seksual/usia $<20$ tahun 2). Banyak pasangan seksual 3). Paparan terhadap IMS 4). Ibu atau saudara perempuan yang mengidap kanker serviks 5). Merokok 6). Penurunan kekebalan tubuh karena HIV/AIDS dan penggunaan kortikosteroid kronis (asthma dan lupus) (Kemenkes RI, 2016).

Setiap 2 menit, seorang wanita di dunia meninggal dunia dan di Asia Pasifik, setiap 4 menit, satu wanita meninggal karena kanker serviks (WHO, 2014). Tahun 2012, kanker serviks termasuk ke dalam empat jenis kanker penyebab utama kematian (266.000 kematian) pada wanita diseluruh dunia dan diprediksi akan meningkat hampir 25\% selama 10 tahun kedepan (tahun 2022).

Menurut GLOBOCAN (2012) di Indonesia, Setiap 1 jam seorang perempuan meninggal karena kanker serviks, estimasi kanker serviks 17 per 100.000 perempuan dan kanker ini merupakan kanker kedua terbanyak pada perempuan di Indonesia (Kemenkes RI, 2017).Laporan dari Yayasan Kanker Indonesia (YKI), ada 15.000 kasus baru setiap tahunnya dan 8000 orang meninggal setelah didiagnosis kanker serviks (Riksani, 2016).

Data Riskesdas 2013, menyebutkan prevalensi kanker serviks di Indonesia adalah
0,8 \%o. Kepulauan Riau, Maluku Utara dan D.I.Yogyakarta merupakan provinsi dengan prevalensi kanker serviks tertinggi, yaitu 1,5\%o. Sedangkan prevalensi terendah ada di Provinsi Gorontalo sebesar 0,0\%o dan Papua Barat sebesar $0,1 \%$. Prevalensi penderita kanker serviks di Jawa Barat juga cukup banyak, yaitu 15.635/0,7\%o (Kemenkes RI, 2015). Berdasarkan laporan Dinkes Kota Bogor, sampai dengan tahun 2018 terdapat 26 kasus kanker serviks dan 4 kematian di Kota Bogor (Dinkes Kota Bogor, 2018).

Kanker serviks dapat menyebabkan penderitaan bagi perempuan yang mengalaminya. Perubahan fisik, psikologis dan juga akan berpengaruh terhadap fungsi peran perempuan (Susanti, Hamid, and Afiyanti, 2011). Sementara dampak bagi negara menurut data Badan Penyelenggara Jaminan Sosial (BPJS), pada tahun 2015 penderita kanker termasuk kanker serviks yang mendapatkan pengobatan telah menghabiskan biaya pengobatan/perawatan sebesar 2,29 triliun rupiah (Kemenkes RI, 2017).

Salah satu upaya pemerintah Indonesia untuk menurunkan prevalensi kanker serviks tertuang dalam Keputusan Menteri Kesehatan No. 796/Menkes/SK/VII/2010 tentang 
Pedoman teknis pengendalian kanker payudara dan kanker leher rahim. Dalam Kepmenkes tersebut dijelaskan upaya pencegahan kanker serviks dapat dilakukan dengan melakukan skrining dengan metode pemeriksaan IVA. Pemeriksaan IVA memiliki kelebihan dibandingkan dengan pap smear, seperti kesederhanaan teknik, biaya rendah, dapat dilakukan di Puskesmas oleh dokter umum dan bidan dan dapat segera memberikan hasil yang dapat digunakan untuk tindakan pengobatan selanjutnya (Kemenkes RI, 2016b).

\section{Rencana Strategis P2PTM (2015-} 2019) Kementerian Kesehatan RI, tahun 2015 menyebutkan bahwa target cakupan pemeriksaan IVA tahun 2015 sebesar 10\%, tahun $2016(20 \%)$, tahun 2017 (30\%), tahun 2018 (40\%) dan tahun 2019 (50\%). Kenyataannya cakupan IVA di Indonesia masih jauh dari yang diharapkan. Berdasarkan data Profil Kesehatan Indonesia (2016) dapat dilihat, cakupan IVA di Indonesia sampai tahun 2016 hanya 5\% dan Jawa Barat sampai tahun 2016 baru 3\%. Sementara itu, cakupan IVA Puskesmas Bondongan tahun 2017 sebanyak $0,8 \%$ dan merupakan cakupan yang terendah diantara 25 Puskesmas yang ada di Kota Bogor.
Health Belief Model (HBM) adalah salah satu teori yang dikembangkan untuk menjelaskan proses perubahan perilaku yang berkaitan dengan kesehatan (Schiavo, 2014). Ada beberapa komponen HBM dalam perubahan perilaku seseorang, salah satunya adalah cues to action (perilaku dipengaruhi oleh suatu hal yang menjadi isyarat bagi seseorang untuk melakukan suatu tindakan atau perilaku). Isyarat bisa bersifat internal (gejalayang dirasakanmeningkatkan ancaman) atau eksternal(pemberitahuan di media, peringatan dari dokter, pemeriksaan sampel, bahkan nasihat atau anjuran teman atau suami/ anggota keluarga lain).

Peran suami dalam membuat keputusan di keluarga yang sangat dominan membuat wanita tidak berdaya untuk memutuskan perawatan dirinya termasuk melakukan skrining kanker serviks (Kangmennaang et al. 2015).Hasil penelitian Yuliwati (2012) di wilayah Puskesmas Prembun, Kabupaten Kebumen menyebutkan ada hubungan yang bermakna antara perilaku wanita usia subur dalam melakukan pemeriksaan IVA dengan dukungan suami $(p=0,000)$. Hasil penelitian ini sejalan dengan penelitian Fitriani (2017) di wilayah kerja Puskesmas Padang Pasir, Kota 
Padang yang menyebutkan ada hubungan yang bermakna antara partisipasi wanita usia subur melakukan pemeriksaan IVA dengan dukungan suami $(p=0,000)$.

Sehubungan dengan penjelasan diatas, peneliti bermaksud untuk melakukan penelitian tentang "Dukungan suami terhadap perilaku WUS (30-50 tahun) dalam melakukan pemeriksaan IVA di wilayah kerja Puskesmas Bondongan, Kota Bogor Tahun 2018". Tujuan dari penelitian ini adalah untuk mengetahui hubungan dukungan suami dengan perilaku WUS (30-50 tahun) dalam melakukan pemeriksaan IVA di wilayah kerja Puskesmas Bondongan, Kota Bogor Tahun 2018

\section{BAHAN DAN METODE}

Penelitian ini merupakan penelitian kuantitatif dengan rancangan cross sectional dimana data yang menyangkut variable bebas (pengetahuan WUS tentang kanker serviks) dan variabel terikat (pemeriksaan IVA) akan dikumpulkan dalam waktu yang bersamaan. Populasi penelitian adalah semua WUS (3550 tahun) baik yang belum pernah melakukan pemeriksaan IVA dan yang sudah pernah melakukan pemeriksaan IVA yang berada di wilayah kerja Puskesmas Bondongan, Kota
Bogor sebanyak 4755 orang. Sampel dalam penelitian ini adalah WUS (30-50 tahun) yang datang ke Puskesmas Bondongan yang memenuhi kriteria inklusi (menikah dan bersedia menjadi responden) dan terpilih sebagai sampel.

Besar sampel dalam penelitian ini ditentukan dengan menggunakan rumus uji hipotesis dua proporsi dan diperoleh sebanyak 59 responden. Teknik pengambilan sampel yang digunakan adalah consecutive sampling, yaitu setiap subjek yang datang secara berurutan dan memenuhi kriteria inklusi penelitian dimasukkan ke dalam penelitian sampai jumlah subjek yang diperlukan terpenuhi. Data dikumpulkan pada bulan NovemberDesember 2018 dengan metode wawancara dan menggunakan kuesioner. Analisis data yang digunakan dalam penelitian ini adalah analisis univariat (distribusi frekuensi) dan bivariat (chi-square)

\section{HASIL DAN PEMBAHASAN}

\section{Analisis Univariat}

Tabel 1. Distribusi Frekuensi Responden berdasarkan Perilaku Pemeriksaan IVA pada WUS (30-50 tahun), Karakteristik dan Dukungan Suami di wilayah kerja Puskesmas Bondongan tahun 2018 


\begin{tabular}{|c|c|c|}
\hline Variabel & Frekuensi & Persentase (\%) \\
\hline \multicolumn{3}{|l|}{ Periksa IVA } \\
\hline Pernah & 16 & 27,1 \\
\hline Tidak pernah & 43 & 72,9 \\
\hline \multicolumn{3}{|l|}{ Usia } \\
\hline$<40$ & 33 & 55,9 \\
\hline$\geq 40$ & 26 & 44,1 \\
\hline \multicolumn{3}{|l|}{ Pendidikan } \\
\hline Tinggi (SMA/PT) & 31 & 52,5 \\
\hline Rendah (SD/SMP) & 28 & 47,5 \\
\hline \multicolumn{3}{|l|}{ Pekerjaan } \\
\hline Tidak bekerja & 49 & 83,1 \\
\hline Bekerja & 10 & 16,9 \\
\hline \multicolumn{3}{|l|}{ Dukungan Suami } \\
\hline Mendukung & 30 & 50,8 \\
\hline Tidak Mendukung & 29 & 49,2 \\
\hline
\end{tabular}

Sumber: Data Primer 2018

Berdasarkan hasil Tabel 1, menunjukkan bahwa responden yang tidak melakukan pemeriksaan IVA lebih banyak dari responden yang melakukan pemeriksaan IVA, sebanyak 43 orang $(72,9 \%)$. Usia responden yang paling banyak adalah usia $\geq 40$ sebanyak 26 orang $(44,1 \%)$. Tingkat pendidikan responden hampir merata untuk masing-masing tingkat pendidikan, paling banyak responden yang berpendidikan tinggi (SMA dan PT) yaitu 31 orang $(52,5 \%)$. Sebagian besar responden yang tidak bekerja, sebanyak 49 orang $(83,1 \%)$. Responden yang mendapat dukungan suami sebanyak 30 orang $(50,8 \%)$.

\section{Analisis Bivariat}

Tabel 2. Hubungan karakteristik dan dukungan suami terhadap perilaku WUS (30-50 tahun) dalam melakukan pemeriksaan IVA

\begin{tabular}{|c|c|c|c|c|c|c|c|}
\hline \multirow{3}{*}{ Variabel } & \multicolumn{4}{|c|}{ Pemeriksaan IVA } & \multirow{2}{*}{\multicolumn{2}{|c|}{ Total }} & \multirow{3}{*}{$\begin{array}{c}P \\
\text { Value }\end{array}$} \\
\hline & \multicolumn{2}{|c|}{ Pernah } & \multicolumn{2}{|c|}{$\begin{array}{c}\text { Tidak } \\
\text { Pernah }\end{array}$} & & & \\
\hline & $\mathrm{n}$ & $\%$ & $\mathrm{n}$ & $\%$ & \multirow[t]{2}{*}{$\mathrm{n}$} & $\%$ & \\
\hline \multicolumn{7}{|l|}{ Usia } & \\
\hline$<40$ & 8 & 24,2 & 25 & 75,8 & 33 & 100 & \multirow{2}{*}{0,791} \\
\hline$\geq 40$ & 8 & 30,8 & 18 & 69,2 & 26 & 100 & \\
\hline \multicolumn{8}{|l|}{ Pendidikan } \\
\hline Tinggi & 9 & 29 & 22 & 71 & 31 & 100 & \multirow{2}{*}{0,956} \\
\hline Rendah & 7 & 25 & 21 & 75 & 29 & 100 & \\
\hline \multicolumn{8}{|l|}{ Pekerjaan } \\
\hline Tidak Bekerja & 11 & 22,4 & 38 & 77,6 & 49 & 100 & \multirow[t]{2}{*}{0,116} \\
\hline Bekerja & 5 & 50 & 5 & 50 & 10 & 100 & \\
\hline \multicolumn{8}{|l|}{ Dukungan } \\
\hline Mendukung & 1 & 3,4 & 28 & 96,6 & 29 & 100 & 0,001 \\
\hline $\begin{array}{l}\text { Tidak } \\
\text { Mendukung }\end{array}$ & & & & & & & \\
\hline
\end{tabular}

Sumber: Data Primer 2018

Hasil tabel 2 diatas menunjukkan dari 59 responden, 33 orang berusia $<40$. Dari 33 responden yang berusia $<40$, terdapat 8 orang $(24,2 \%)$ yang pernah melakukan pemeriksaan IVA dan 25 orang $(75,8 \%)$ yang tidak melakukan pemeriksaan IVA. Sementara itu, dari 26 responden yang berusia $\geq 40$ sebanyak 8 orang $(30,8 \%)$ pernah melakukan pemeriksaan IVA dan 18 orang $(69,2 \%)$ tidak melakukan pemeriksaan IVA. Hasil uji 
chi-square diperoleh nilai $\mathrm{p}=0,791$, dapat disimpulkan tidak ada hubungan antara usia dengan perilaku WUS (30-50 tahun) dalam melakukan pemeriksaan IVA.

Sementara itu, dari 59 responden, terdapat 31 orang yang berpendidikan tinggi dan 29 orang yang berpendidikan rendah.Dari 31 responden yang memiliki pendidikan tinggi hanya 9 orang (29\%) yang pernah melakukan pemeriksaan IVA dan 22 orang (71\%) yang tidak melakukan pemeriksaan IVA, sedangkan dari 29 responden yang berpendidikan rendah, terdapat 7 orang $(25 \%)$ reponden yang melakukan pemeriksaan IVA dan 21 orang (75\%) yang tidak melakukan pemeriksaan IVA. Hasil uji chi-square diperoleh nilai $\mathrm{p}=0,956$, dapat disimpulkan tidak ada hubungan antara pendidikan dengan perilaku WUS (30-50 tahun) dalam melakukan pemeriksaan IVA.

Variabel pekerjaan menunjukkan bahwa dari 59 responden, terdapat 49 orang yang tidak bekerja dan 10 orang yang bekerja. Dari 49 responden yang tidak bekerja hanya 11 orang $(22,4 \%)$ yang pernah melakukan pemeriksaan IVA dan 38 orang $(77,6 \%)$ tidak melakukan pemeriksaan IVA. Sementara itu, dari 10 responden yang bekerja, antara yang melakukan pemeriksaan IVA dan yang tidak melakukan pemeriksaan IVA jumlahnya seimbang, masing-masing 5 orang (50\%). Hasil uji chi-square diperoleh nilai $\mathrm{p}=0,116$ dapat disimpulkan tidak ada hubungan antara pekerjaan dengan perilaku WUS (30-50 tahun) dalam melakukan pemeriksaan IVA.

Berbeda dengan variabel-variabel yang sudah disebutkan, untuk variabel dukungan suami dari 59 responden, terdapat 30 orang mendapat dukungan suami dan 29orang yang tidak mendapat dukungan. Dari 30 responden yang mendapat dukungan suami, sebanyak 15 orang $(50 \%)$ pernah melakukan pemeriksaan IVA dan 15 orang (50\%) tidak melakukan pemeriksaan IVA. Sementara itu, dari 29 responden yang tidak mendapat dukungan suami, hanya 1 orang $(3,4 \%)$ yang pernah melakukan pemeriksaan IVA, selebihnya 28 orang $(96,6 \%)$ tidak melakukan pemeriksaan IVA. Hasil uji chi-square diperoleh nilai $\mathrm{p}=0,001$, artinya ada hubungan antara dukungan suami dengan perilaku WUS (30-50 tahun) dalam melakukan pemeriksaan IVA.

\section{Hubungan Usia dengan perilaku WUS (30-50 tahun) dalam melakukan pemeriksaan IVA}

Usia responden dibagi menjadi dua kelompok, yaitu usia $<40$ dan usia $\geq 40$. 
Kelompok usia dikategorikan berdasarkan usia terbaik (optimal) bagi WUS dalam melakukan deteksi dini kanker leher rahim metode IVA. Usia 40 tahun dijadikan batasan karena insiden kanker serviks sangat sedikit pada perempuan dengan umur dibawah 25 tahun, insidens akan meningkat sekitar usia 35 tahun keatas dan menurun pada usia menopause. Sehingga usia deteksi dini atau program penapisan di Indonesia perlu dilakukan 10 tahun lebih awal/ difokuskan pada usia 30-50 tahun dan sudah melakukan hubungan seksual (Mc Pherson, et.al 2000 dalam Kemenkes RI 2016c). Berdasarkan hasil penelitian, responden yang berusia $<40$, terdapat 8 orang $(24,2 \%)$ pernah melakukan pemeriksaan IVA dan responden yang berusia $\geq 40$ sebanyak 8 orang $(30,8 \%)$ pernah melakukan pemeriksaan IVA. Hasil uji chi-square diperoleh nilai $\mathrm{p}=0,791$, artinya tidak ada hubungan yang bermakna antara usia dengan perilaku WUS (30-50 tahun) dalam melakukan pemeriksaan IVA.

Hasil penelitian yang dilakukan oleh (Aulia, 2016a), menyebutkan dari 60 responden terdapat 35 orang $(58,3 \%)$ berusia $<40$ tahun dan hanya $9(25,7 \%)$ yang pernah melakukan pemeriksaan IVA, sedangkan responden yang berusia $\geq 40$ tahun sebanyak 25 orang $(41,7$ $\%)$ dan hanya 6 orang (24\%) yang pernah melakukan deteksi dini kanker leher rahim dengan metode IVA. Berdasarkan uji statistik didapatkan nilai $\mathrm{p}=1,0$ yang menunjukkan bahwa tidak terdapat hubungan yang bermakna antara umur dengan perilaku deteksi dini kanker leher rahim metode IVA pada WUS di Puskesmas Padang Pasir, Kota Padang Tahun 2016. Selain itu, hasil penelitian Parapat, (2016) di wilayah kerja Puskesmas Candiroto, menyebutkan bahwa tidak ada hubungan antara kelompok umur berisiko dan kelompok umur tidak berisiko dengan perilaku deteksi dini kanker leher rahim $(\mathrm{p}=0,07)$.

Usia adalah lamanya waktu perjalanan hidup responden yang dihitung sejak ia lahir sampai pada saat pelaksanaan wawancara yang dinyatakan dalam satuan tahun. Menurut Kemenkes RI (2016b) tes kanker atau prakanker dianjurkan bagi semua perempuan berusia 3050 tahun.Penderita kanker serviks tertinggi terdapat pada wanita berusia 40-50 tahun, sehingga tes harus dilakukan pada usia dimana lesi prakanker lebih mungkin untuk dideteksi 10 sampai 20 tahun lebih awal.

Penelitian di Rwanda (2013) menyebutkan bahwa usia rata-rata dari wanita yang datang untuk skrining adalah 37 tahun, sebagian besar antara umur 30 dan 35 tahun (47,7\%). 
Hasil penelitian ini menunjukkan tingginya partisipasi wanita muda dalam melakukan skrining kanker serviks (Makuza et al., 2015). Sementara itu penelitian di Namibia menyebutkan bahwa wanita yang lebih tua lebih berpartisipasi melakukan skrining kanker serviks, meskipun manfaat skrining lebih rendah pada kelompok usia yang lebih tua (risiko yang lebih rendah untuk lesi prakanker dan invasif) dibandingkan dengan wanita usia reproduksi (Kangmennaang et al. 2015)

Secara Psikologis, seharusnya usia dewasa yang lebih tua lebih banyak melakukan tindakan pencegahan karena merasa lebih rentan terhadap masalah kesehatan tertentu (Sarafino, 2014). Menurut Aulia(2016), usia yang dianjurkan bagi WUS untuk melakukan deteksi dini kanker leher rahim adalah usia dibawah 40 tahun, karena pada masa itulah perjalanan penyakit dari kanker leher rahim baru dimulai dan dapat segeradiatasi. Semakin cepat seseorang melakukan deteksi dini kanker serviks ( $<40$ tahun) maka akan semakin cepat pula kemungkinan kanker serviks dapat diobati.

Menurut asumsi peneliti, tidak adanya hubungan yang bermakna antara usia dengan perilaku WUS (30-50 tahun) dalam melakukan pemeriksaan IVA di wilayah kerja Puskesmas
Bondongan tahun 2018, kemungkinan dikarenakan oleh faktor lain seperti ketidak tahuan responden bahwa di Puskesmas Bondongan dapat dilakukan pemeriksaan IVA. Sejalan dengan Yuliwati (2012), yang menyebutkan bahwa umur tidak bisa menjadi patokan dalam melakukan pemeriksaan IVA secara rutin dan tepat waktu, kemungkinan dikarenakan oleh ketidaktahuan, tidak ada keluhan, takut mengetahui hasil pemeriksaan, rasa malu dan menganggap pemeriksaan IVA tidaklah penting.

\section{Hubungan Pendidikan dengan perilaku} WUS (30-50 tahun) dalam melakukan pemeriksaan IVA

Pendidikan terakhir responden dibedakan pada dua kategori, yaitu pendidikan tinggi (>SMP) dan pendidikan rendah $(\leq \mathrm{SMP})$. Pembagian kategoripendidikan didasarkan pada UU RI No. 20 Tahun 2003 tentang Sistem Pendidikan Nasional. Berdasarkan hasil penelitian, responden yang berpendidikan tinggi, terdapat 9 orang (29\%) pernah melakukan pemeriksaan IVA dan responden yang berpendidikan rendah sebanyak 7 orang (25\%) pernah melakukan pemeriksaan IVA. Hasil uji chi-square diperoleh nilai $\mathrm{p}=0,956$, artinya tidak ada hubungan yang bermakna 
antara pendidikan dengan perilaku WUS (3050 tahun) dalam melakukan pemeriksaan IVA.

Hasil penelitian Kartika (2015) di wilayah kerja Puskesmas Kecamatan Jatinegara, menyebutkan dari 105 responden yang diteliti, responden yang berpendidikan rendah sebanyak 8 orang $(25,8 \%)$ yang perilaku periksa IVA nya baik, dan 23 orang $(74,2 \%)$ yang perilaku periksa IVA nya kurang baik. Sementara itu, responden yang berpendidikan tinggi sebanyak 24 orang $(32,4 \%)$ perilaku periksa IVA nya baik dan 50 orang $(67,6 \%)$ perilaku periksa IVA nya kurang baik. Hasil uji chi-square menunjukkan bahwa tidak ada hubungan signifikan antara pendidikan dengan perilaku WUS dalam deteksi dini kanker serviks dengan metode pemeriksaan IVA(nilai $\mathrm{p}=0,660$ ). Hasil penelitian Girsang (2013) juga menyebutkan tidak terdapat hubungan yang bermakna antara pendidikan dengan tindakan IVA test yang dilakukan oleh ibu warga Desa Limau Manis $(p=0,265)$.

Pendidikan adalah proses pengubahan sikap dan tata laku seseorang atau kelompok orang dalam usaha mendewasakan manusia melalui upaya pengajaran dan pelatihan, proses, cara, perbuatan mendidik (KBBI). Pendidikan merupakan upaya persuasi atau pembelajaran kepada masyarakat agar masyarakat mau melakukan tindakan-tindakan (praktik) untuk memelihara (mengatasi masalah-masalah) dan meningkatkan kesehatannya. Tindakan pemeliharaan dan peningkatan kesehatan yang dihasilkan oleh pendidikan kesehatan didasarkan pada pengetahuan dan kesadarannya melalui proses pembelajaran(Notoatmodjo, 2014).Secara teori, pendidikan merupakan salah satu faktor yang mempengaruhi pembentukan perilaku dan pola hidup, termasuk perilaku kesehatan. Semakin tinggi pendidikan seseorang, semakin tinggi kemampuannya untuk menerima pengetahuan, semakin baik pula perilaku kesehatannya (Aulia, 2016). Pendidikan mempengaruhi proses belajar, semakin tinggi pendidikan seseorang maka semakin mudah seseorang untuk menerima informasi. Selain itu, dengan pendidikan tinggi maka seseorang cenderung untuk mendapatkan informasi baik dari orang lain maupun dari media massa (Kartika, 2015).

Menurut asumsi peneliti, tidak adanya hubungan yang bermakna antara usia dengan perilaku WUS (30-50 tahun) dalam melakukan pemeriksaan IVA di wilayah kerja Puskesmas Bondongan tahun 2018, 
kemungkinan dikarenakan oleh faktor lain seperti ketersediaan waktu responden dalam melakukan pemeriksaan IVA, pengalaman seseorang, keterpaparan informasi terkait kanker serviks dan pemeriksaan IVA, dukungan orang sekitar. Harwati (2015) menyebutkan dalam penelitiannya bahwa tidak ada hubungan pendidikan dengan perilaku skrining kanker serviks, kemungkinan disebabkan oleh pendidikan yang tinggi tidak diikuti dengan perolehan informasi terkait dengan kanker serviks dan skrining/deteksi dini kanker serviks.

\section{Hubungan Pekerjaan dengan perilaku WUS (30-50 tahun) dalam melakukan pemeriksaan IVA}

Pekerjaan responden dibedakan pada dua kategori, yaitu tidak bekerja (IRT) dan bekerja (PNS, Buruh). Pembagian kategori pendidikan didasarkan pada Undang-Undang Tenaga Kerja No.13 tahun 2003 tentang ketenaga kerjaan. Hasil penelitian menunjukkan, responden yang tidak bekerja, terdapat 11 orang $(22,4 \%)$ pernah melakukan pemeriksaan IVA dan responden yang bekerja sebanyak 5 orang (50\%) pernah melakukan pemeriksaan IVA. Hasil uji chi-square diperoleh nilai $\mathrm{p}=0,956$, artinya tidak ada hubungan yang bermakna antara pendidikan dengan perilaku WUS (3050 tahun) dalam melakukan pemeriksaan IVA.

Hasil penelitian Kartika (2015) di wilayah kerja Puskesmas Kecamatan Jatinegara menyebutkan dari 105 responden yang diteliti, responden yang tidak bekerja sebanyak 26 orang $(29,9 \%)$ yang melakukan pemeriksaan IVA dan 61 orang $(70,1 \%)$ tidak melakukan pemeriksaan IVA. Sementara itu, responden yang bekerja sebanyak 6 orang $(33,3 \%)$ melakukan pemeriksaan IVA dan 12 orang $(66,7 \%)$ tidak melakukan pemeriksaan. Hasil uji chi-square menunjukkan bahwa tidak ada hubungan signifikan antara pekerjaan dengan perilaku WUS dalam deteksi dini kanker serviks dengan metode pemeriksaan IVA (nilai $\mathrm{p}=0,994)$. Penelitian ini juga sejalan dengan hasil penelitian Yuliwati (2012), menyebutkan tidak ada hubungan yang signifikan antara pekerjaan dengan perilaku WUS dalam melakukan pemeriksaan IVA di Wilayah Puskesmas Prembun, Kabupaten Kebumen $(p=0,459)$.

Pekerjaan adalah suatu rangkaian tugas yang dirancang untuk dikerjakan oleh satu orang dan sebagai imbalan diberikan upah dan gaji menurut kualifikasi dan berat ringannya pekerjaan tersebut (Kemenaker dan BPS, 2014). Wanita Usia Subur (WUS) yang bekerja 
kemungkinan lebih banyak terpapar informasi tentang kanker serviks dibandingkan dengan WUS yang tidak bekerja, yang menghabiskan waktu dirumah (Sarini, 2011). Wanita yang bekerja lebih memiliki pengetahuan tentang kanker serviks dan melakukan skrining dibandingkan dengan wanita yang tidak bekerja di Kenya (Kangmennaang et al. 2018). Menurut Yuliwati (2012), WUS yang bekerja lebih banyak menghabiskan waktunya di tempat kerja dan tidak sempat melakukan pemeriksaan IVA, sementara jam operasional pemeriksaan IVA di puskesmas/RS hanya dilakukan pada jam kerja.

Menurut asumsi peneliti, tidak adanya hubungan yang bermakna antara pekerjaan dengan perilaku WUS (30-50 tahun) dalam melakukan pemeriksaan IVA di wilayah kerja Puskesmas Bondongan tahun 2018, kemungkinan dikarenakan oleh faktor lain seperti kurangnya informasi terkait jadwal pemeriksaan IVA,persepsi WUS terhadap ancaman dari kanker serviks dan manfaat dari pemeriksaan IVA bukan karena tidak ada waktu. Hal ini didukungdari hasil penelitian yang menunjukkan bahwa $83,1 \%$ WUS tidak bekerja.SeharusnyaWUS tersebut memiliki waktu/kesempatan lebih besar untuk melakukan pemeriksaan IVA, namun pada kenyataannya tidak demikian. Dewi (2014),menyebutkan bahwaWUS yang tidak bekerja memiliki waktu luang yang lebih banyak untuk melakukan pemeriksaaan IVA namun arus informasi mengenai pemeriksaan IVA cenderung lebih sedikit.

\section{Hubungan Dukungan Suami dengan perilaku WUS (30-50 tahun) dalam melakukan pemeriksaan IVA}

Suami adalah orang pertama dan utama dalam memberi dorongan kepada istri sebelum pihak lain turut memberi dorongan, dukungan dan perhatian seorang suami terhadap istri (Butarbutar, 2014). Hasil penelitian menunjukkan responden yang mendapat dukungan suami, terdapat 15 orang $(50 \%)$ pernah melakukan pemeriksaan IVA dan responden yangkurang mendapat dukungan suamihanyalorang $(3,4 \%)$ pernah melakukan pemeriksaan IVA. Hasil uji chisquare diperoleh nilai $\mathrm{p}=0,001$, artinya ada hubungan yang bermakna antara dukungan suami dengan perilaku WUS (30-50 tahun) dalam melakukan pemeriksaan IVA.

Hasil penelitian Henzayana (2017) Di Wilayah Kerja Puskesmas Lubuk Buaya, Kota Padang menyebutkan dari 90 responden yang diteliti, responden yang mendapat dukungan 
suami sebanyak13 orang (72,2\%) yang melakukan pemeriksaan IVA dan 5 orang $(27,8 \%)$ tidak melakukan pemeriksaan IVA. Sementara itu, responden yang tidak mendapat dukungan suami, tidak satu pun $(0 \%)$ yang melakukan pemeriksaan IVA dan72 orang $(100 \%)$ tidak melakukan pemeriksaan. Hasil uji chi-square menunjukkan ada hubungan signifikan antara dukungan suami dengan tindakan WUS dalam deteksi dini kanker serviks dengan metode pemeriksaan IVA (nilai $\mathrm{p}=0,000)$. Penelitian ini juga sejalan dengan hasil penelitian Fitriani (2017) di Puskesmas Padang Pasir Kota Padang yang menyebutkan ada hubungan yang bermakna antara dukungan suami dengan partisipasi WUS melakukan pemeriksaan IVA $(p=0,000)$.

Suami dan keluarga merupakan orang terdekat dengan WUS dalam berinteraksi dan mengambil keputusan, terutama dalam menentukan kemana akan mencari pertolongan atau pengobatan (Yuliwati, 2012). Faktor penting dalam memberikan dorongan bagi ibu untuk melakukan pemeriksaan deteksi dini kanker leher rahim adalah orang-orang terdekat yaitu suami dan keluarga (Purba, 2011). Dukungan suami/ keluarga dapat memberikan keuntungan emosional yaitu memberikan individu rasa nyaman dan memberikan semangat dalam pelaksanaan tindakan individu yang memberi penguatan akan rasa dimiliki atau dicintai atau berpengaruh pada tingkah laku termasuk dalam melakukan deteksi dini kanker serviks (Henzayana, 2017).

Menurut asumsi peneliti, adanya hubungan yang bermakna antara dukungan suami dengan perilaku WUS (30-50 tahun) dalam melakukan pemeriksaan IVA di wilayah kerja Puskesmas Bondongan tahun 2018kemungkinan karena suami merekatelah mendapat informasi mengenai kanker serviks dan pentingnya pemeriksaan IVA. Saat ini informasi kesehatan sudah mudah di dapatkan melalui media komunikasi seperti internet terlebih di kota besar. Seorang suami yang mengetahui informasi tentang pentingnya pemeriksaan IVA, ia tentu akan menyarankan kepada isterinya untuk melakukan pemeriksan IVA. Parapat (2016) menyebutkan dukungansuami sangat berperan dalampengambilan keputusan istri, karena suami memiliki posisi tertinggi dalam keluarga. Sarini (2011) menyebutkan bahwa pria merupakan sasaran yang potensial untuk mendapat informasi mengenai kanker serviks dan pemeriksaan IVA.Penelitian di Kenya menyebutkan bahwa kurangnya dukungan suami, seperti tidak bersedia mendanai biaya skrining menjadi salah satu 
faktor penghambat dalam melakukan skrining kanker serviks (Orang'o, Wachira, Asirwa, Bushakala, \& Naanyu, 2016).

\section{KESIMPULAN DAN SARAN}

Kesimpulan dari penelitian ini adalah ada hubungan yang bermakna antara dukungan suami dengan perilaku WUS (30-
50 tahun) dalam melakukan pemeriksaan IVA di wilayah kerja Puskesmas Bondongan tahun 2018. Diharapkan kepada petugas kesehatan Puskesmas Bondongan untuk terus mensosialisasikan melalui penyuluhanpenyuluhan tentang kanker serviks dan pentingnya pemeriksaan IVA kepada WUS (30-50 tahun) dan juga kepada suami.

\section{DAFTAR PUSTAKA}

Aulia, Desi. 2016. "Health Beliefs Model (HBM) Perilaku Deteksi Dini Kanker Leher Rahim Metode Iva Pada Wanita Usia Subur Di Puskesmas Padang Pasir Tahun 2016”. Skripsi. Universitas Andalas.

Butarbutar MH. 2014. Pengaruh Pengetahuan dan Sikap Ibu Serta Dukungan Suami Terhadap IVA (Inspeksi Visual Asam Asetat) di Wilayah Kerja Puskesmas Helvetia Medan Tahun 2014. Tesis. Universitas Sumatera Utara

Dewi, Luthfiana. 2014. "Faktor - Faktor Yang Berhubungan Dengan Perilaku Wanita Usia Subur Dalam Deteksi Dini Kanker Serviks Dengan Metode Pemeriksaan Inspeksi Visual Asam Asetat (IVAa) Di Wilayah Kerja Puskesmas Tanjung Hulu Pontianak Timur Tahun 2014. ”Universitas Tanjungpura.

Dinas Kesehatan Kota Bogor. 2018. Laporan Tahun Sie. PTM.Dinkes Kota Bogor

Dinas Kesehatan Provinsi Jawa Barat. 2016. Profil Kesehatan Jawa Barat

Fitriani, Yessy. 2017. "Faktor Yang Berhubungan Dengan Partisipasi Wanita Usia Subur Melakukan Pemeriksaan Inspeksi Visual Asam Asetat (IVA) Di Wilayah Kerja Puskesmas Padang Pasir Kota Padang Tahun 2017." Skripsi.Universitas Andalas.

Girsang, Lasmatiur. 2013. "Determinan Ibu Terhadap Pemeriksaan Inspeksi Visual Asetat (IVA) Di Desa Limau Manis Wilayah Kerja Puskesmas Tanjung Morawa Kabupaten Deli Serdang Tahun 2013.” Universitas Sumatera Utara. 
ISSN: 1858-3385, EISSN: 2549-7006

GASTER Vol. 17 No. 2 Agustus 2019

GLOBOCAN 2012: Estimated Cancer Incidence, Mortality and Prevalence Worldwide in 2012. WHO: IARC

Harwati, Reniy Andriati. 2015. “Determinan Perilaku Wanita Usia Subur Dalam Skrining Kanker Serviks Di Wilayah Kerja Puskesmas Kecamatan Ciracas Tahun 2015.’.Tesis. Universitas Indonesia.

Henzayana, Siska. 2017. “Faktor-Faktor Yang Mempengaruhi Tindakan Wus Dalam Deteksi Dini Kanker Serviks Metode IVA di Wilayah Kerja Puskesmas Lubuk Buaya Tahun 2017. ’Skripsi. Universitas Andalas.

Kangmennaang, Joseph, Nandini Thogarapalli, Paul Mkandawire, and Isaac Luginaah. 2015.

"Investigating the Disparities in Cervical Cancer Screening among Namibian Women." Gynecologic Oncology, 6. http://dx.doi.org/10.1016/j.ygyno.2015.05.036.

Kangmennaang, Joseph; Elizabeth; Onyango, Isaac; Luginaah, and Susan Elliott. 2018. "The next Sub Saharan African Epidemic? A Case Study of the Determinants of Cervical Cancer Knowledge and Screening in Kenya." Social Science \& Medicine, 10. https://doi. org/10.1016/j.socscimed.2017.12.013.

Kartika, AA. 2015. "Faktor-Faktor Yang Berhubungan Dengan Praktek Wanita Usia Subur Dalam Deteksi Dini Kanker Serviks Dengan Metode IVA Di Wilayah Kerja Puskesmas Kecamatan Jatinegara Tahun 2015. ’Skripsi. Universitas Indonesia.

Kemenkes RI. 2015. “Infodatin, Stop Kanker.” Jakarta.

Kemenkes RI. 2016a. Buku Acuan Pencegahan Kanker Payudara dan Kanker Leher Rahim . 2016b. Pedoman Teknis Pengendalian Kanker Payudara \& Kanker Leher Rahim. Jakarta: Kemenkes RI.

Kemenkes RI.2017. Profil Kesehatan Indonesia 2016

Kemenaker dan BPS. 2014.Klasifikasi Baku Jabatan Indonesia (KBJI). Jakarta: Kemenaker dan BPS

Keputusan Menteri Kesehatan No. 796/Menkes/SK/VII/2010 tentang Pedoman teknis pengendalian kanker payudara dan kanker leher rahim. 
Makuza, Jean;, Sabin; Nsanzimana, Marie; Muhimpundu, Lydia; Pace, Joseph; Ntaganira, and David Riedel. 2015. "Prevalence and Risk Factors for Cervical Cancer and PreCancerous Lesions in Rwanda." Pan African Medical Journal, 9. https://doi.org/10.11604/ pamj.2015.22.26.7116.

Notoatmodjo, Soekidjo. 2014. Ilmu Perilaku Kesehatan. Jakarta: Rineka Cipta

Orang'o, Omenge Elkana;, Juddy; Wachira, Fredrick; Asirwa, Nafthali; Bushakala, and Violet; Naanyu. 2016. "Factors Associated with Uptake of Visual Inspection with Acetic Acid (VIA) for Cervical Cancer Screening in Western Kenya.” Plos One Juni: 13. https://doi. org/DOI:10.1371/journal.pone.0157217.

Parapat, Theodora Flora. Setyawan, HenrySaraswati, Dian Lintang. . 2016. Faktor Faktor Yang Berhubungan Dengan Perilaku Deteksi Dini Kanker Leher Rahim Metode Inspeksi Visual Asam Asetat di Puskesmas Candiroto Kabupaten Temanggung. Jurnal Kesehatan Masyarakat (Oktober, 2016)

Purba, Evy Misriawaty. 2011. Faktor-faktorr yang berhubungan dengan Pap Smear Pada Pasangan Usia Subur (PUS) di Puskesmas Belawan Kota Medan Tahun 2011. Skripsi. Depok: FKM UI

Riksani, Ria. 2016. Kenali Kanker Serviks Sejak Dini. Edited by Maya. Yogyakarta: Andi Offset Sarafino, Edward P. (1994). Health Psychologi, Biopsychosocial Interaction. Edisi ketujuh. New York : John Wiley \& Sons, Inc

Sarini, Ni Ketut Manik. 2011. Faktor-Faktor Yang Berhubungan Dengan Perilaku pemeriksaan Pap Smear Pada Wanita Usia Subur di Desa Pacung Wilayah Kerja Puskesmas Tejakula II, Kecamatan Tejakula, Kabupaten Buleleng, Provinsi Bali Tahun 2011. Skripsi. Depok: FKM UI

Schiavo, Renata. 2014. Health Communication From Theory To Practice. Second edi. San Francisco: Jossey-Bass.

Susanti, Dahlia Dwi, Yani S Achir Hamid, and Yati Afiyanti. 2011. "Pengalaman Spiritual Perempuan Dengan Kanker Serviks.” Jurnal Keperawatan Indonesia 14: 
ISSN: 1858-3385, EISSN: 2549-7006

GASTER Vol. 17 No. 2 Agustus 2019

Yuliwati. 2012. Faktor-Faktor yang Berhubungan dengan Perilaku WUS dalam Deteksi Dini Kanker Leher Rahim Metode IVA di Wilayah Puskesmas Prembun Kabupaten Kebumen Tahun 2012. Skripsi: Universitas Indonesia

WHO. 2014.World Cancer Report 2014. Edited by Bernard W. Stewart and Christopher P. Wild. Switzerland: IARC 